\title{
The impact of environmental policy instruments on innovation: A review of energy and automotive industry studies
}

\author{
Anna Bergek and Christian Berggren
}

\section{Linköping University Post Print}

Tweet

N.B.: When citing this work, cite the original article.

Original Publication:

Anna Bergek and Christian Berggren, The impact of environmental policy instruments on innovation: A review of energy and automotive industry studies, 2014, Ecological Economics, (106), 112-123.

http://dx.doi.org/10.1016/j.ecolecon.2014.07.016

Copyright: Elsevier

http://www.elsevier.com/

Postprint available at: Linköping University Electronic Press

http://urn.kb.se/resolve?urn=urn:nbn:se:liu:diva-111539 


\title{
The impact of environmental policy instruments on innovation: a review of energy and automotive industry studies
}

\author{
Anna Bergek ${ }^{\mathrm{a}, *}$ and Christian Berggren ${ }^{\mathrm{a}}$ \\ ${ }^{a}$ KITE research group, Department of Management and Engineering, Linköping University, SE-58183 \\ Linköping, Sweden. E-mail: anna.bergek@liu.se (A. Bergek); christian.berggren@liu.se (C. Berggren).
}

\begin{abstract}
Various types of policy instruments have been implemented to reduce local and global emissions, but the impact on innovation of different instruments has received less attention. This paper reviews empirical studies of the innovation impact of four main types of policy instruments in two high-emitting sectors. The conclusions are threefold. (1) Policy plays a key role for the development and diffusion of environmental innovation in the studied sectors. (2) Different types of instruments promote different types of innovations: general economic instruments has primarily encouraged incremental innovation, general regulatory instruments has enforced improvements based on modular innovation, and technologyspecific instruments appears to have been needed to support the development and deployment of radically new technologies. (3) All types of policy instruments face challenges in design and implementation: understanding the selection impact of the chosen instruments, implementing increasing stringency levels, committing to an appropriate scale, and safeguarding policy stability.
\end{abstract}

Key words: Environmental policy; innovation; policy instruments 


\section{Introduction}

Government policies, from regulatory standards to economic incentives, are vital for innovations not directly related to customer benefits, such as various types of emissions reduction. Since the 1960s, authorities in the OECD-countries and emerging economies have sought ways to encourage technological development to reduce pollution from production plants and mobile sources. More recently, global greenhouse emissions have come into focus, especially for high-emitting sectors, such as transport and energy generation. A variety of instruments have been applied, from technology-forcing standards or market incentives for specific technologies, to general economic instruments, such as $\mathrm{CO}_{2}$ taxes and emission allowances trading systems.

The primary goal of environmental policies is to reduce polluting emissions. In this respect, it is often argued that general economic instruments, such as taxes, are more efficient in inducing adoption of emission-reducing technologies than regulatory, "command-andcontrol" (CAC-) measures ${ }^{1}$, such as emissions regulation for specific products or plants (Bergquist et al., 2013; Jaffe et al., 2002). The core argument is that with general, marketconforming instruments, relevant actors will invest where the cost of pollution abatement is

\footnotetext{
${ }^{1}$ The juxtaposition of "market-based instruments" with the somewhat derogative term "command and control" measures can be misleading. The negative externality represented by polluting emissions is not internalized by the market just because a tax or trading system is introduced. On the contrary, such instruments, e.g. the European emissions trading system, rely on administrative measurement, reporting and control of actual emissions for their functioning. A proper terminology, analogous with "command and control" would refer to "tax and control" or "trade and control".
} 
lowest, thus maintaining economic efficiency, whereas subsidies of specific technologies or industries may lead to lock-in effects, as the subsidies of one technology which once seemed promising crowd out other more potent technologies not envisaged at the time of the decision (cf. Jaffe et al., 2005; OECD, 2005). ${ }^{2}$

The focus of this paper is, however, the "side-effects" of environmental policy instruments in terms of their impact on innovation, i.e. the development, market introduction and early diffusion of new products and processes rather than the adoption of already commercially available technologies. Such effects have received less attention in the literature and the conclusions so far are partially conflicting. One the one hand, studies based on microeconomic modeling argue that "instruments which provide incentives through the price mechanism, by and large, perform better than command and control policies" (Requate, 2005: 193); one important reason for this is that with a standard firms lack incentives to perform beyond the pre-determined level, while economic instruments such as pollution taxes induce firms to reduce pollution beyond that standard. ${ }^{3}$ On the other hand, empirical comparisons of the innovation impact of various instruments have demonstrated that direct regulation "could imply a greater spur to technology adoption and innovation

\footnotetext{
${ }^{2}$ Many economists also point out that there can be other obstacles for environmentally benign technologies to develop and diffuse. For example, positive externalities tend to make investments lower than socially desirable, which implies that various other policy interventions, e.g. R\&D subsidies and tax credits, might be needed to support technology development and adoption (Fischer et al., 2012; Jaffe et al., 2002). The effects of such technology and innovation policies are not studied in this paper.

${ }^{3}$ This of course presumes that the cost of further pollution reduction by investing in new equipment, e.g., is less than the cost of the avoided tax.
} 
than market-based instruments" and that "... there appears to be little evidence of one policy instrument being superior compared to others in promoting environmental compliance and innovation" (Bergquist et al., 2013: 7-8).

Existing studies of the innovation impact of policies for environmental innovation tend to focus on one or a few instruments or specific cases of pollution. In a recent review of empirical studies of environmental policy, Kemp and Pontoglio (2011) concluded that the context in which policy instruments are applied is important for their outcomes. Although many contextual factors might influence innovation, several of these can be captured under the umbrella term of 'sector'. Sectors differ with regard to general framework conditions for innovation, such as infrastructural requirements, capital intensities, technological linkages, performance parameters, as well as with regard to the resulting patterns of technical change (cf. Malerba, 2002; Pavitt, 1984). This implies that an analysis comparing effects of various instruments in different sectors would make a fruitful complement to the many country-specific studies of particular pollution reduction cases (for a recent overview, see Bergquist, et al. (2013)) and may provide important input for more informed decisionmaking and policy debates. ${ }^{4}$

Against this background, the purpose of this paper is to present a review of empirical studies of the innovation effects of four main types of policy instruments in two high-

\footnotetext{
${ }^{4}$ Comparisons of countries may provide general insights on regulatory regimes, for example comparisons of the US regime of central control with the more flexible and collaborative approaches pursued in European countries (Löfstedt and Vogel, 2001), but their contextuality makes them less suited to analyze the impact of specific instrument types.
} 
emitting sectors: the automotive sector and the energy sector. By such a comparison, we can arrive at a richer understanding of different types of policies in terms of their impact, applicability and limits, but we have no ambition to draw normative conclusions with regard to whether specific policy instruments should be used or not. That depends on, among other things, what the goal of a specific environmental policy intervention is in terms of whether innovation is at all asked for and, in that case, what type of innovation is wanted.

The paper is outlined as follows. In Section 2, we present a framework for classifying (environmental) policy instruments and discussing their impact on innovation, which distinguishes between four types of policy instrument and four types of innovation. In Section 3, we discuss research design, including case selection and how we identified the studies that are included in the review. In Section 4, we review the identified empirical studies and synthesize their findings with regard to the innovation impact of different types of environmental policy instruments. Section 5 contains our conclusions, a discussion of further relevant observations and some suggestions for future research.

\section{A framework for policy and innovation classification}

The aim of this paper is to scrutinize available empirical evidence of the innovation impact of different types of environmental policy instruments, by means of a two-sector comparative approach. We structure the review using a framework that distinguishes different types of policy instruments and discuss their impact on four different types of 
innovation. It should be noted that this paper is limited to technological product and process innovations, i.e. organizational innovations are not included.

\subsection{Policy instrument typology}

Two main distinctions are made with regard to instrument type. First, in line with previous literature on environmental policy, we distinguish between economic and regulatory (prescriptive) instruments. ${ }^{5}$ Second, we distinguish between general and technologyspecific instruments. In some cases there may be a grey zone between what could be seen as "general" and "specific", but the distinction has been widely used in the literature where the relative pros and cons of general vs. technology-specific instruments is an important issue (cf., e.g., Sandén and Azar, 2005).

Some recent literature argues that the innovation impact of policy instruments is mediated or even determined - by design features rather than by instrument types (cf, e.g., Bergquist et al., 2013; Brouillat and Oltra, 2012; Kemp and Pontoglio, 2011). In particular, several studies (cf. Johnstone et al., 2010a; Rogge et al., 2011; Yin and Powers, 2010) discuss the influence of stringency (how difficult or expensive it is for market actors to comply) and predictability (how certain and foreseeable the policy signal is). However, the literature has also recognized the difficulty of measuring and comparing such features across countries

\footnotetext{
${ }^{5}$ Considering that economic instruments are also regulated, a more correct term would be "direct regulatory instruments" (cf. Goulder and Parry, 2008). For reasons of simplicity, we nevertheless use the shorter term "regulatory instrument" instead.
} 
and sectors (Johnstone et al., 2010a). Considering this, we do not include design features in our comparative analysis. We will return to this issue in the discussion section.

\subsubsection{Economic vs. regulatory policy instruments}

Economic instruments aim at providing actors with incentives to adopt low-emission technologies: actors who invest in sustainable solutions should receive an economic compensation corresponding to the avoided social cost of pollution, whereas actors who invest in a polluting technology should be economically punished. Firms are then expected to undertake pollution control efforts in their own interest (Stavins, 2003). Regulatory instruments (often referred to as direct regulation) aim at controlling the actions of firms, for example via technological standards (i.e. prescription of a certain method, equipment or technology), emission standards (an absolute upper emission level), and performance standards, such as a cap on emissions per unit of output. Other types of regulatory instruments include bans or prescribed use of certain solutions and permits for building and operation of plants. Whereas some of these regulations are compulsory, others are optional, i.e. firms can choose whether or not to comply, but non-compliance may come with a penalty or other negative consequences.

According to Requate (2005) instruments that work through the price mechanism offer incentives for private actors to develop improved technologies and make it attractive for firms to clean up more than mandated if feasible technologies are available (cf. also Bergquist et al., 2013; Jaffe et al., 2002; Stavins, 2003). It can, however, be politically difficult to, for example, set high enough carbon taxes to induce the required innovation efforts (Fischer et al., 2012). Moreover, the impact of price incentives on innovation can be 
limited in markets where buyers only carry a fraction of the actual cost of use. One example is the construction sector where owners of multi-tenant houses seldom are the actual endusers and do not carry the cost of use, e.g. the penalty of poor insulation (Noailly, 2012). Similar problems exists in the automotive sector, where the life-time value of a more efficient product exceeds the perceived value for the first customer who only includes the savings during the first 2-3 years at the time of their buying decisions (Greene, 2010).

With regard to regulatory instruments, it has been shown that performance and technology standards can pressure firms to develop products and processes to meet the requirements (Grubb and Ulph, 2002), as long as standards cannot be achieved with current technologies (Jaffe et al., 2002; Popp et al., 2009). It can, however, be costly for firms to develop technologies to meet regulatory standards (Lee et al., 2010), and this, it is argued, might reduce the overall means available for innovation (cf. Chappin et al., 2009; Jaffe et al., 2002).

\subsubsection{Technology-specific vs. general instruments}

General environmental policy instruments aim at increasing sustainability without pinpointing any particular technology (Sandén and Azar, 2005). Examples include taxes and cap-and-trade systems, such as the European Union Emissions Trading System (EU ETS). General instruments can also be found at lower levels of aggregation. They are then aimed at a group of technologies (e.g. renewable energy technologies), but do not distinguish between technologies within that group. Technology-specific instruments directly support or regulate specific technologies. They include technology-specific 
standards and requirements, as well as various types of support to innovation: R\&D funding, public procurement, and demonstration and market support.

When comparing various policies, proponents of general instruments tend to use the efficiency argument: general instruments will achieve diffusion of technologies in a cost efficient way whereas the support of specific technologies comes at the expense of other, potentially better technologies and implies a risk of postponing their development (cf. Jaffe et al., 2005; Popp et al., 2009). Proponents of technology-specific instruments argue that general policy instruments mainly benefit already commercially available technologies, whereas technology-specific policies, such as $R \& D$, demonstration, niche market creation, network support and standard setting, are needed to stimulate the various product and process innovations that eventually can make immature technologies available for selection within the frame of more general policy instruments (Sandén and Azar, 2005). Otherwise, such technologies will stay in the laboratory or be confined to small niche markets.

\subsubsection{A combined policy classification framework}

If we combine the categorizations discussed above, four main types of environmental policy instruments can be distinguished: general economic instruments, general regulatory instruments, technology-specific economic instruments and technology-specific regulatory instruments (see Figure 1). 


\begin{tabular}{l|c|c|}
\multicolumn{1}{c}{} & \multicolumn{1}{c}{ Economic } & Regulatory \\
\cline { 2 - 3 } General & $\begin{array}{c}\text { General } \\
\text { economic }\end{array}$ & $\begin{array}{c}\text { General } \\
\text { regulatory }\end{array}$ \\
\cline { 2 - 3 } $\begin{array}{l}\text { Technology- } \\
\text { specific }\end{array}$ & $\begin{array}{c}\text { Technology- } \\
\text { specific } \\
\text { economic }\end{array}$ & $\begin{array}{c}\text { Technology- } \\
\text { specific } \\
\text { regulatory }\end{array}$ \\
\cline { 2 - 3 } & &
\end{tabular}

Figure 1: Four types of policy instruments

\subsection{Innovation typology}

Kemp and Pontoglio (2011) and Demirel and Kesidou (2011) argue that there is a need to qualify the concept of innovation further when studying the effects of policy. A first distinction to be made is between technology adoption and innovation. As discussed by Jaffe et al. (2005), emissions reductions require technology adoption, i.e. the gradual replacement of older technologies by new ones in various applications and firms. This is the main aim of environmental policy. Before technologies can be widely diffused, however, they need to be developed, industrialized and commercialized. It is the latter that we define as innovation. Innovation is not a linear progression from $R \& D$ to market introduction, but a complex, interactive process, where experiences from experiments, early applications and niche markets are fed back to research, development, design, production and marketing (Kline and Rosenberg, 1986). ${ }^{6}$ Innovation, thus, involves market formation

\footnotetext{
${ }^{6}$ For example, the modern silicon-based solar cell was developed at Bell Laboratories in the 1950s, but with a conversion efficiency of only 4-5 percent and a cost of several hundred USD/ $\mathrm{W}_{\mathrm{p}}$ it was utterly impractical (Perlin, 1999), with the exception of some early niche markets (Andersson and Jacobsson, 2000). On the basis
} 
and early stages of diffusion of technologies that are not yet fully developed, but it does not include widespread deployment of already available and commodity-like "off-the shelf" technologies (cf. Bergquist et al., 2013; Sandén and Azar, 2005). Innovations do not have to be new to the world, but new to the firms that develop them and to the market where they are introduced. In the specific context of environmental innovation, the focus is on novelties that lead to better environmental performance. Consequently, we define environmental innovation as the development, market introduction and early diffusion of new or refined technologies which reduce undesirable emissions.

One implication of this definition is that we, in contrast to Foray et al. (2012), focus on policies implicitly or explicitly aiming at the development, commercialization and early adoption of new technologies (including further performance enhancement and process development), rather than on policy instruments directed only at the early phases of discovery and invention (e.g. R\&D support schemes). Another implication is that pure diffusion policies, e.g. instruments directed at further adoption of already commercially available solutions, are excluded from the analysis.

Within this overall definition, different types of innovation can be distinguished. Innovation typologies tend to be either competence-based or market-based (Bergek et al., 2013; Macher and Richman, 2004). In this paper, we use the well-known, competence-based Henderson and Clark (1990) typology, which is particularly relevant for analysing

of this humble start, a stream of innovations in design, configuration, materials and manufacturing have paved the way for the rapid uptake currently taking place. 
innovations in complex technologies and products such as vehicles or power generation equipment. This typology distinguishes four types of innovations based on their impact on individual components and the overall architecture of the product: incremental innovations involve smaller improvements in individual components; modular innovations involve additions to, or substantial changes in, the core design concept of one or more component(s); architectural innovations involve the reconfiguration of existing components into a new product architecture; and radical innovations involve substantial changes in components as well as product architecture (see Figure 2).

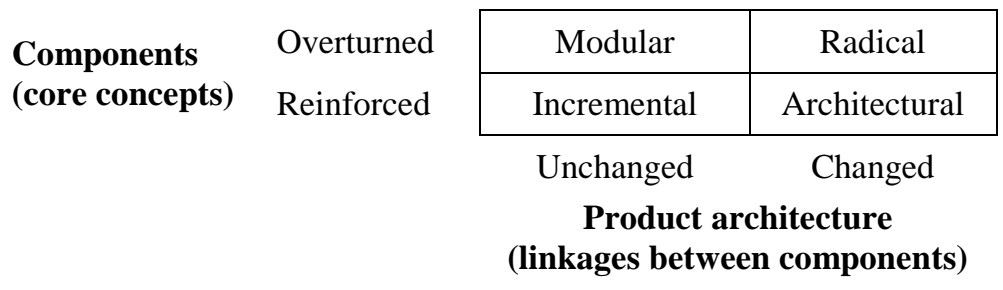

Figure 2: Innovation typology (elaboration on Henderson and Clark (1990)).

This typology implies that for an environmental policy instrument to have an innovation impact, it should stimulate incremental, modular, architectural or radical changes in a product or process. This effect could be direct, or it could be indirect, by supporting early market formation and further improvements. Moreover, to be considered "innovation" the new or improved product or process should also be introduced on the market.

It should be noted that not all performance improvements are due to innovation as defined here. Most notably, cost reductions are often the result of increased labour efficiency, work 
specialization and product standardization, rather than a result of innovation in our sense (cf. Junginger et al., 2005). ${ }^{7}$

\section{A two-sector comparative approach}

\subsection{Case selection and sector characteristics}

The paper builds on published research in peer-reviewed journals related to the automotive and energy sectors. We chose these sectors for three reasons. First, both are capitalintensive, high-emitting sectors, and have been subject to a broad range of policies; hence there are instances of all four types of policy instruments in both sectors (see Table 1). Second, both sectors are dominated by a limited number of incumbent actors who have few incentives apart from government policies to accelerate the introduction of sustainable innovations, considering that the production and distribution of their current technologies are closely connected to existing, large-scale production systems and infrastructures (Weyant, 2011). Third, both sectors are based on complex products which integrate a number of components and sub-systems, some of which are complex products in themselves. Innovation can therefore take place at several different levels: at component/sub-system level, at system (architectural) level or at both.

The two sectors also differ in several important aspects. The energy sector is characterized by long product life cycles, slow turnover of existing equipment, low volume production of

\footnotetext{
${ }^{7}$ This implies that studies using cost-reductions as their outcome measure without demonstrating that innovation is indeed the cause of these reductions (cf., e.g., Söderholm and Klaassen, 2007) are not included in the review.
} 
new equipment (with the exception of solar cells and, to some extent, wind turbines), and low operating costs per unit in existing large-scale systems. Significant reduction of $\mathrm{CO}_{2}$ emissions in this sector requires technological leaps, either in the form of expensive auxiliary equipment, such as the addition of carbon capture and storage (CCS) technology to existing coal burning power plants, or a switch to renewable energy technologies (the exception being the substitution of biomass for fossil fuels, a realistic option only in some countries). The sector is characterized by a vigorous competition between different technologies, and improvement in the cost, efficiency and availability of one technology might considerably increase its market share (although there are also plenty of obstacles to the diffusion of renewable energy technologies, see for example Jacobsson and Johnson (2000) and Foxon et al. (2005)). In the automotive industry, product life cycles are shorter, the stock of products is turned over more rapidly and mass production of a few selected technologies is the norm. Modular innovations are continuously introduced which makes it possible to use policy instruments to relatively rapidly enforce new standards regarding e.g. safety or emissions. We assume that such differences can result in different patterns of innovation and policy interventions. At the same time, similarities across sectors will strengthen the value of the observations.

An alternative approach would have been to focus on a particular technology, e.g. wind power or technology for producing biogas for vehicles, and compare the impact of different types of policies across different institutional settings (e.g. countries). Although such an approach might have allowed us to study how country-specific characteristics influence the effect of environmental policy on innovation, a main problem is the lack of available 
empirical studies with such a focus. Although there are cross-country comparative studies of innovation processes in specific technologies (cf., e.g., Bergek and Jacobsson, 2003; Hillman et al., 2008; Lovio and Kivimaa, 2012; Praetorius et al., 2010; van Alphen et al., 2009; Vasseur et al., 2013), most of these do not discuss the innovation outcomes of specific policy instruments (those that do are included in our review). It would have been even more difficult to find empirical evidence of the innovation outcome of all four types of policy instruments. We have therefore opted for the broader, sector-focused approach.

Table 1: Examples of environmental economic and regulatory policy instruments in the automotive and energy sectors (categorization based on the specific instruments analyzed in the reviewed literature)

\begin{tabular}{|c|c|c|c|c|}
\hline & \multicolumn{2}{|l|}{ Economic } & \multicolumn{2}{|l|}{ Regulatory } \\
\hline & Automotive & Energy & Automotive & Energy \\
\hline General & $\begin{array}{l}=\mathrm{CO}_{2} \text { tax on } \\
\text { transport fuels }\end{array}$ & $\begin{array}{l}\text { - Emissions trading } \\
\text { schemes } \\
\text { - Refunded } \mathrm{NO}_{\mathrm{x}} \\
\text { emissions } \\
\text { payments } \\
\text { - Tradable } \\
\text { renewable } \\
\text { certificate (TGC) } \\
\text { systems }\end{array}$ & $\begin{array}{l}\text { Emissions } \\
\text { regulation } \\
\left(\mathrm{e} . \mathrm{g} . \mathrm{NO}_{\mathrm{x}}\right. \\
\mathrm{SO} \text { and } \\
\left.\mathrm{CO}_{2}\right)\end{array}$ & $\begin{array}{l}\text { - Emissions } \\
\text { regulation for } \\
\text { power plants } \\
\left(\mathrm{SO}, \mathrm{NO}_{\mathrm{x}}\right) \\
\text { - Energy } \\
\text { performance } \\
\text { regulation for } \\
\text { buildings }\end{array}$ \\
\hline $\begin{array}{l}\text { Technology- } \\
\text { specific }\end{array}$ & $\begin{array}{l}\text { - Subsidies for } \\
\text { specific } \\
\text { alternative fuels } \\
\text { - Public } \\
\text { procurement of } \\
\text { specific } \\
\text { technologies }\end{array}$ & $\begin{array}{l}\text { - Fixed tariffs for } \\
\text { renewable } \\
\text { electricity }\end{array}$ & $\begin{array}{l}\text { - Californian } \\
\text { zero- } \\
\text { emissions } \\
\text { vehicle } \\
\text { (ZEV) } \\
\text { mandate }\end{array}$ & $\begin{array}{l}\text { - Identification of } \\
\text { Best Available } \\
\text { Techniques } \\
\text { (BAT) } \\
\text { - Technology- } \\
\text { specific rules } \\
\text { for permits, } \\
\text { land-use etc. }\end{array}$ \\
\hline
\end{tabular}

\subsection{Identification of empirical evidence of innovation impacts}

The review is focused on articles in scientific journals. We conducted a key word search for articles in the Science Direct full text database, using key words such as "policy", 
“environmental", "instrument", "innovation”, "regulation", "energy", "automotive” and "car" in different combinations. We also used keywords related to specific instruments, e.g. "EU ETS", “emissions trading”, "cap-and-trade” etc. Through these searchers, we identified both some relevant studies and a number of relevant journals (e.g. Energy Policy, Ecological Economics, Energy Economics, Journal of Environmental Economics and Management, Research Policy, Technology Analysis \& Strategic Management, Technological Forecasting and Social Change and Technovation). We scanned these journals further for papers on sustainability, innovation and policy, using a broad search strategy. The final comprehensive literature search was conducted in January 2013.

Based on title and abstract of the articles we found through all these searches (general keywords, specific keywords and journal searches), we identified a number of potentially relevant articles that we read in their entirety. Using references in these papers we identified other sources, applying a snowballing method until no more references with significant new information could be found. We also consulted recent review articles, e.g. Kemp and Pontoglio (2011) and Popp et al. (2009).

To be included in our review, articles had to be based on empirical studies of the innovation impact, as defined above, of some type of policy instrument in one of our two sectors. In line with our definition of innovation, we included studies of new-to-the-market technologies, products and systems as well as refinement and addition to existing ones, but not studies of large-scale diffusion of existing products and processes or general cost reductions. No further selection was made within the resulting sample, i.e. the review includes all empirical studies that we could find that meet these criteria. 
After categorizing the studies according to our policy typology (see Table 2), we noticed that some types of policy instruments were not covered by the identified literature. Most notably, studies of energy-related technology-specific regulatory instruments were missing entirely. We therefore used a new set of even more specific key words searches to identify literature related to specific instruments (e.g. "BAT and innovation"). However, this did not result in any additional relevant studies. Although there are plenty of instances of, e.g., best available technology standards, scientifically published evaluations of their innovation impacts have not been available. When reading the synthesis, this lack of evidence for some types of instruments should be taken into account.

\subsection{Comparative analysis}

It should be noted that this literature review is not intended to be a meta study. The studies reported here are a combination of case studies and patent analyses, which means that it is not possible to aggregate data and results to make statistical calculations. The review and the synthesis of the results are, thus, of a qualitative nature.

Making a comparative analysis of a diverse set of studies involves two main challenges. ${ }^{8}$ First, environmental policy instruments are often combined with each other and with other instruments, related to e.g. R\&D or innovation policies. This can make it difficult to isolate the impact of a particular instrument. Since we are relying on studies published in peerreviewed journals, we trust that the researchers behind these studies have managed to do so in a satisfactory way. Moreover, even when there is a mix of instruments in a sector, some

\footnotetext{
${ }^{8}$ We are grateful for the suggestion by one of the reviewers to discuss these challenges more explicitly.
} 
of these are more critical than others. ${ }^{9}$ We argue that the approach in this paper, where we synthesize several studies and compare two different sectors, makes it possible to single out these critical instruments.

Second, policy instruments could have impacts beyond the primary object of study. Instruments implemented in one country can, of course, stimulate innovation in other countries, especially when supply-chains are international. This implies that the innovation impact of some instruments might be underestimated if the geographical scope of the analysis is too narrow. Again we are limited by the empirical delineations of the included studies. Some of these study innovation impacts across national borders whereas others are confined to individual countries (see Table 2). There is, however, little reason to suspect that this would work to the disadvantage of any particular type of policy instrument.

\footnotetext{
${ }^{9}$ For example, European countries in Europe early on spent significant resources in supporting wind turbine R\&D. But only a few of them, notably Denmark and Germany, succeeded in making this R\&D efforts part of industrial development and early diffusion. Compare with neighboring Sweden for example, where the sums spent on wind power R\&D and early demonstrations miserably failed to drive any industrialization and diffusion (Bergek and Jacobsson, 2003). In this case, feed-in tariffs were a key driver of positive interactions with other instruments, which by themselves would be much less productive.
} 
Table 2: Studies included in the review (in chronological order within each category)

\begin{tabular}{|c|c|c|c|c|c|}
\hline Type & Sector & Instrument & Articles found & Corresponding journal & Country $^{\mathrm{a}}$ \\
\hline \multirow{13}{*}{$\begin{array}{l}\text { General } \\
\text { economic }\end{array}$} & \multirow[t]{2}{*}{ Automotive } & \multirow[t]{2}{*}{ Fuel taxes } & Greene (1990) & The Energy Journal & US \\
\hline & & & Clerides and Zachariadis (2008) & Energy Economics & 18 countries \\
\hline & \multirow[t]{11}{*}{ Energy } & \multirow[t]{4}{*}{ ETS } & Popp (2003) & Journal of Policy Analysis and Management & US \\
\hline & & & Taylor et al. (2005) & Technological Forecasting \& Social Change & US \\
\hline & & & Rogge and Hoffman (2010) & Energy Policy & $\mathrm{DE}$ \\
\hline & & & Rogge et al. (2011) & Energy Economics & $\mathrm{DE}$ \\
\hline & & NOx refunds & Sterner and Turnheim (2009) & Ecological Economics & SE \\
\hline & & \multirow[t]{6}{*}{ TGC } & Foxon et al. (2005) & Energy Policy & UK \\
\hline & & & Butler and Neuhoff (2008) & Renewable Energy & $\mathrm{UK}, \mathrm{DE}$ \\
\hline & & & do Valle Costa et al. (2008) & Renewable and Sustainable Energy Reviews & UK, NL, DE \\
\hline & & & Verbruggen (2009) & Energy Policy & $\mathrm{BE}$ \\
\hline & & & Bergek and Jacobsson (2010) & Energy Policy & SE \\
\hline & & & Johnstone et al. (2010b) & Environmental and Resource Economics & 28 countries \\
\hline \multirow{11}{*}{$\begin{array}{l}\text { General } \\
\text { regulatory }\end{array}$} & \multirow{5}{*}{ Automotive } & \multirow{5}{*}{$\begin{array}{l}\text { CAAA, CAFE and } \\
\text { similar European } \\
\text { emissions regulations }\end{array}$} & Greene (1990) & The Energy Journal & US \\
\hline & & & Knecht (2008) & Energy & Europe \\
\hline & & & Bauner et al. (2009) & Clean Technologies and Environmental Policy & SE \\
\hline & & & Lee et al. (2010) & Technovation & US \\
\hline & & & Berggren and Magnusson (2012) & Energy Policy & Europe, US \\
\hline & \multirow[t]{6}{*}{ Energy } & \multirow[t]{3}{*}{ CAA(A) } & Bellas (1998) & Resource and Energy Economics & US \\
\hline & & & Bañales-López and Norberg-Bohm (2002) & Energy Policy & US \\
\hline & & & Popp (2006) & Journal of Environmental Economics and Management & DE, JP, US \\
\hline & & \multirow[t]{3}{*}{ Building regulations } & Beerepoot and Beerepoot (2007) & Energy Policy & NL \\
\hline & & & Noailly and Batrakova (2010) & Energy Policy & NL \\
\hline & & & Noailly (2012) & Energy Economics & 7 countries \\
\hline \multirow{9}{*}{$\begin{array}{l}\text { Technology- } \\
\text { specific } \\
\text { economic }\end{array}$} & \multirow[t]{2}{*}{ Automotive } & Fuel subsidies & No empirical studies found & & \\
\hline & & Public procurement & Sushandoyo and Magnusson (2014) & Journal of Cleaner Production & SE, UK \\
\hline & \multirow[t]{7}{*}{ Energy } & \multirow{7}{*}{$\begin{array}{l}\text { Feed in tariffs and } \\
\text { investment subsidies }\end{array}$} & Jacobsson and Lauber (2006) & Energy Policy & $\overline{\mathrm{DE}}$ \\
\hline & & & Del Río and Gual (2007) & Energy Policy & ES \\
\hline & & & Butler and Neuhoff (2008) & Renewable Energy & $\mathrm{UK}, \mathrm{DE}$ \\
\hline & & & Del Río González (2008) & Energy Policy & ES \\
\hline & & & Negro and Hekkert (2008) & Technology Analysis \& Strategic Management & $\mathrm{DE}$ \\
\hline & & & Büsgen and Dürrschmidt (2009) & Energy Policy & $\mathrm{DE}$ \\
\hline & & & Johnstone et al. (2010b) & Environmental and Resource Economics & 28 countries \\
\hline \multirow{2}{*}{$\begin{array}{l}\text { Technology- } \\
\text { specific } \\
\text { regulatory }\end{array}$} & Automotive & ZEV & Pilkington et al. (2002) & World Patent Information & US \\
\hline & Energy & BAT standards etc. & No empirical studies found & & \\
\hline
\end{tabular}

regulatory

${ }^{\mathrm{a}} \mathrm{DE}=$ Germany. ES = Spain. JP = Japan. NL = The Netherlands. SE = Sweden. UK = United Kingdom. US = United States of America. 


\section{Review of studies of the innovation impact of environmental policy instruments in the automotive and energy sectors}

Both the automotive and the energy sectors have a long history of environmental policy interventions and all four types of policy instruments have been applied in both sectors (see Table 2 for an overview of the instruments discussed in this paper).

In the automotive sector, the US in the 1960s was the birthplace of regulatory intervention to reduce local noxious emissions. Similar efforts are now in place or being implemented to reduce greenhouse gas emissions, for example new Corporate Average Fuel Economy (CAFE) standards in the US and legal standards for $\mathrm{CO}_{2}$-emissions from new cars in the EU. In addition, there are a multitude of technology-specific subsidies for so-called 'clean' vehicles and fuels, such as ethanol and electric cars.

The energy sector has been influenced by government policies for a very long time. In the last decades, two main policy trajectories have emerged: (i) specific attempts to support the development and diffusion of low-carbon technologies with the potential to replace fossil fuels and (ii) general policy measures, such as the European Emissions Trading Scheme (EU ETS) to reduce greenhouse gas emissions.

\subsection{Effects of general economic instruments on innovation}

General economic instruments in the automotive sector include $\mathrm{CO}_{2}$ levies and other taxes related to transport fuels. Plenty of studies have investigated the effect of such instruments on the diffusion of existing technologies, for example the differences between the car markets in North America and Western Europe (50 percent diesel share 
in Europe vs. 3 percent in the US (Berggren et al., 2009). However, few researchers study their impact on the development and diffusion of new technologies. In a comparison of the effects of regulatory standards versus prices on long-term automobile fuel economy, Clerides and Zachariadis (2008) found that standards had more impact on fuel efficiency than taxes. This is related to the problem of achieving a sufficient stringency level when implementing economic instruments; to stimulate innovation, fuel taxes, for example, need to be highly salient, which politically is hard to realize (Sterner, 2012). Thus, the empirical evidence indicates that price instruments are less effective than direct regulation in driving the development of low-emitting technologies (Greene, 1990). When fuel taxes do have any impact on innovation it tends to be of the incremental type, improvement and fine-tuning in existing components and systems. Thus, in spite of the huge differences in fuel taxes between the US and Western Europe, there is no evidence that this difference is related to significant differences in technological these knowledge and innovation capabilities (Sterner, 2012). ${ }^{10}$

In the energy sector, the dominant general economic instruments are $\mathrm{CO}_{2}$ taxes and emissions trading schemes (ETS). In Sweden, a system with refunded emissions payments (REP) for $\mathrm{NO}_{\mathrm{x}}$ abatement has also been used. There are also various quasigeneral instruments supporting the development and diffusion of renewable energy technology, such as tradable green certificate (TGC) systems.

Emissions trading have become a favourite instrument among economists on the basis of their assumed successes in cleaning up coal-fired power plants in the US in the 1980s.

\footnotetext{
${ }^{10}$ Whereas in Western Europe the average tax in 2008 equaled 119 US cents/liter gasoline (and slightly higher in the UK), the US fuel tax only amounted to 13 cents/liter (Sterner, 2012).
} 
However, most of the emission reductions came from switching to low-sulphur fuels or installing scrubbers. Judging by patent data this technology had been developed before the trading system was implemented, although there are some indications that the efficiency of new scrubbers increased after the implementation of the trading system (Popp, 2003). In a similar way Taylor et al. (2005) found little evidence that the trading program established by the 1990 Clean Air Act Amendments induced any significant innovation in $\mathrm{SO}_{2}$ emissions control technologies. The system seems to have stimulated some incremental innovation, but its main effect was to increase diffusion of an existing technology.

In Europe, the EU ETS from 2005 is currently the key instrument for reducing greenhouse emissions from power plants and energy-intensive industries. It puts a cap on the allowed emissions from large, stationary greenhouse gas emitters and, based on this cap, distributes allowances to the emitters, which they can use or sell to other companies. Studies of EU ETS-related innovations in Germany have found that “... the innovation impact of the EU ETS on low or zero-carbon mitigation options tends to be very limited" (Rogge et al., 2011: 520). The EU ETS has resulted in a significant increase in $R \& D$ and demonstration projects on efficiency improvements and has also stimulated research and demonstration projects on carbon capture and storage (CCS), but it has not been enough to encourage full-scale industrialization and market introduction of this technology. The effect on RD\&D on renewables has been limited, especially with regard to wind power; the EU ETS complements (and sometimes negatively interacts with) the existing favourable framework conditions for diffusion of 
renewables, but does not drive e.g. wind turbine development (Rogge and Hoffmann, 2010).

Another type of economic instrument, refunded emissions payments (REP) was implemented in Sweden in 1992. Combustion plants over a certain size had to pay a fee based on their yearly $\mathrm{NO}_{\mathrm{x}}$ emissions and the fees were refunded to the plants based on their yearly production of useful energy, which benefitted plants with lower-thanaverage emission intensity (Sterner and Turnheim, 2009). An analysis of the affected plants shows that the average emission intensity was reduced with nearly $50 \%$ in the period of 1992-2005. This reduction was the result of fuel switching, incremental "trimming" of combustion parameters and adoption of already available, often modular abatement technologies (e.g. low- $\mathrm{NO}_{\mathrm{x}}$ burners and catalysts) rather than of any new innovations (Sterner and Turnheim, 2009).

The final general economic instrument we will consider is TGC systems, i.e. productiondependent allocations of tradable certificates to renewable electricity producers, combined with obligations for consumers or suppliers to buy certificates corresponding to a certain share ("quota") of their electricity consumption/sales (i.e. a regulatory instrument). From a longitudinal, cross-country study of patent data, Johnstone et al.(2010b: 148) conclude that renewable energy certificates and obligations in general have had a positive effect on patenting for technologies that are quite near to the market, but they have not "encouraged innovation on technologies that are further from market, such as solar energy." This study, however, does not provide any detailed analysis of what types of innovations patents refer to. 
Studies of individual countries show a similar and somewhat more detailed picture. Here we will focus on experiences of TGCs in the UK, Sweden and Flanders. ${ }^{11}$ The UK Renewables Obligation came into effect in 2002. According to several studies, the system has primarily promoted land-based wind power, biomass, landfill gas and sewage gas, i.e. technologies that in the UK context can be considered 'near-market' technologies (cf. do Valle Costa et al., 2008; Foxon et al., 2005). The effects on innovation are mainly restricted to incremental learning-by-doing by global manufacturers (Foxon et al., 2005). The system has not encouraged the development of technologies which in the UK are seen as promising options for the future, such as offshore wind, solar cells and wave/tidal power, since they are too expensive and/or considered too risky (Butler and Neuhoff, 2008). The Swedish electricity certificate system came into force in 2003 and, similar to the UK system, has primarily benefited actors who invest in relatively mature technologies; in 2008 , for example, $70 \%$ of the renewable production in the system consisted of biomass-based electricity production in industrial back-pressure plants and combined heat and power plants, whereas novel technologies found it hard to compete within the TGC regime (Bergek and Jacobsson, 2010). The outcome of the TGC system in Flanders is similar. Although Verbruggen (2009) shows that some projects included innovations, in that they took advantage of waste flows in agriculture and industry, the author concluded that from an innovation perspective "[t]he predominance of bio-waste conversion ... is rather worrying" (ibid.:

\footnotetext{
${ }^{11}$ For detailed descriptions of the systems, see Mitchell et al. (2006) (UK), Wood and Dow (2011) (UK), Bergek and Jacobsson (2010) (Sweden) and Verbruggen (2009) (Flanders).
} 
1392). Again, the main effects of the trading instrument are related to incremental improvements and changes in diffusion patterns of established technologies.

\subsection{Effects of general regulatory instruments on innovation}

General regulatory instruments in the automotive sector include regulation of tailpipe emissions (e.g. $\mathrm{NO}_{\mathrm{x}}, \mathrm{SO}$, particulate matter, and $\mathrm{CO}_{2}$ ) and legislation forcing fuel suppliers to blend a certain share of renewable fuels into gasoline (e.g. the European Commission's $10 \%$ mandate $^{12}$ and the US Renewable Fuels Standard). Here, we will focus on the innovation impact of the US Clean Air Act Amendment (CAAA) of 1970 and subsequent emissions reduction legislation.

After a period of escalating criticism of automotive pollution, and mounting political pressure (Tao et al., 2010), Congress passed the path-breaking Clean Air Amendment Act (CAAA) in 1970. As a consequence of CAAA, the automotive industry was required to achieve a $90 \%$ reduction in $\mathrm{HC}, \mathrm{CO}$ and $\mathrm{NO}_{\mathrm{x}}$ emissions by $1975 / 76$ compared to the levels in 1970. In 1990, Congress further increased the stringency of the Clean Air Act, by requiring reductions from the 1990 levels of HC and NOx of 35\% and $60 \%$, respectively (the Tier I-standard). The EPA set even more stringent standards to be phased in between 2004 and 2009. Compared to the 1970 levels, this Tier II-standard mandated a reduction of $\mathrm{HC}$ and $\mathrm{CO}$ emissions of $98 \%$ and $95 \%$, respectively. As Lee et al. (2010) show, the industry after an initial period of resistance responded by expanding its innovation efforts: overall patenting in emissions control technologies increased from virtually no patents in 1970 to almost 100 US patents granted per year in the mid-1970s,

${ }^{12}$ Directive 2009/28/EC. 
and the patented inventions were rapidly implemented in new mass-produced components. According to their analysis, these patenting efforts quickly subsided when the stringency level was unchanged in the 1980s, but increased to new heights in the 1990s when more stringent standards were introduced or announced. The CAAA was effective in driving development and mass diffusion of modular innovations, e.g. catalyst technologies, which could be added to conventional vehicles without changing their basic architectures, but also contributed to generic innovations in electronic controls which laid the basis for modern engine management systems.

Inspired by the development in the US, the EU in the early 1990s introduced a comprehensive framework for eliminating noxious emissions from gasoline and diesel engines, starting with the EU I level (1992), followed by gradually tightened standards through Euro II (1996), Euro III (2000), Euro IV4 (2005) and Euro V (2009), to Euro VI (2014) ${ }^{13}$. This prolonged period of greatly increased stringency levels has resulted in a $90 \%$ reduction of more of noxious pollutants have been in new EU-registered vehicles. A side effect has been significant advances in combustion diagnostics, sensors, electronic control, and engine management systems (Bauner et al., 2009; Knecht, 2008).

The US automotive market has also been subject to fuel economy standards, in the form of the Energy Policy and Conservation Act of 1975, which required the corporate average fuel economy (CAFE) of manufacturers' fleets to meet increasingly strict targets. In an analysis of the first 12 years of the CAFE standards, Greene (1990)

\footnotetext{
${ }^{13}$ European Council Directive 98/69 relating to measures to be taken against air pollution by emissions from motor vehicles and European Council Regulation No 715/2007 on type approval of motor vehicles with respect to emissions from light passenger and commercial vehicles.
} 
showed that this regulatory instrument had a significant effect on product plans and product development at the American car makers - an effect that remained in force also when gasoline prices collapsed in the mid-1980s. This study, however, does not provide much information about the types of innovation that were achieved.

In 2008, EU legislated restrictions for vehicular $\mathrm{CO}_{2}$ emissions, with the first step amounting to on average of $130 \mathrm{~g} \mathrm{CO}_{2} / \mathrm{km}$ to be legally implemented $2012-15$ and the next step (95 $\left.\mathrm{g} \mathrm{CO}_{2} / \mathrm{km}\right)$ envisaged for 2020. This regulation has been driving development, improvement and diffusion of a number of existing technologies, such as turbo charging, direct ignition, dual clutch transmission, start/stop systems and more advanced valve management systems; anticipating the regulation, car makers already in 2008 made more progress in reducing emissions than in any of the previous ten years (Berggren and Magnusson, 2012). ${ }^{14}$

The US Clean Air Act also applies in the energy sector, where it regulates $\mathrm{SO} / \mathrm{NO}_{\mathrm{x}}$ emissions from power plants (from 1990 complemented by an emissions trading system as discussed above). ${ }^{15}$ According to a study by Bañales-López and Norberg-Bohm (2002), the CAA was explicitly expected to provide a "pull” for advanced clean coal technologies, but largely failed to do so. With regard to $\mathrm{SO}_{\mathrm{x}}$, the main reason was that cheaper options such as scrubbers were available, as described above, and the regulation

\footnotetext{
14 This progress was not a transitory phenomenon, but continued in the following years; in 2009-10 the European car makers reduced emissions in their new models by a $10 \%$ reduction to an average of $140 \mathrm{~g}$ $\mathrm{CO}_{2} / \mathrm{km}$ per car, close to the target for 2015 (Dings, 2010, 2011).

${ }^{15}$ Initially in the form of performance standards (percentage reduction of emissions); from 1990 in the form of an emission limit per MBtu heat input (Taylor et al., 2005).
} 
neither improved the efficiency of new scrubbers (Popp, 2003), nor their cost (Bellas, 1998). ${ }^{16}$

With regard to $\mathrm{NO}_{\mathrm{x}}$, Popp (2006) shows that US patenting activities related to postcombustion, add-on reduction techniques increased by a factor of 11 between 1982 and 1990, but these inventions were only commercialized to a very limited extent, and in year 2000 less than 4 percent of the US coal-fired power plants used the new techniques. By contrast, in Germany and Japan patenting peaks in post-combustion techniques following regulation were combined with widespread diffusion (to over 50 percent of the plants in 2000). This might be another indication that regulation stringency matters for turning inventions into innovations - "although both the US and Japanese enacted similar $\mathrm{NO}_{\mathrm{x}}$ regulations in the early 1970 s, US regulations soon lagged behind those of Japan and Germany" (Popp, 2006: 50).

In addition to these emissions regulations, there are also general regulative instruments aimed at reducing the use of energy, e.g. the EU Buildings Directive from 2003, which obliges all EU member states to implement energy performance regulation for buildings. Such regulation was introduced in the Netherlands already in 1996, based on an energy performance coefficient (EPC), which provides a generalized measure of the energy efficiency of a building. The first EPC was set at a level corresponding to standard building practice in 1996 (defined as 1.4) and has been tightened three times: to 1.2 in 1998, to 1.0 in 2000 and to 0.8 in 2006 (Noailly and Batrakova, 2010). Patent analyses

\footnotetext{
${ }^{16}$ Considering this, it is interesting to note that the US recently adopted the ACES act, which sets strict $\mathrm{CO}_{2}$ emissions standards for coal plants from 2012. Some claim that these standards can only be met by CCS technology (van Alphen et al., 2010).
} 
show that following this regulation the number of energy-efficiency patents applied for by Dutch firms increased in the mid-1990s, although this trend then leveled off (Noailly and Batrakova, 2010). Similar patenting trends have been observed in other European countries, conditioned by the level of stringency of the standards (Noailly, 2012).

With regard to the types of innovation induced by these performance standards, Beerepoot and Beerepoot (2007) conclude that the Dutch building regulations contributed to incremental innovation in terms of improved efficiency in conventional water heating technologies, such as gas condensing boilers and district heating, but did not result in the development or diffusion of any "really new" innovations, such as solar hot water boilers or heat pumps. In our terminology, the latter would be described as modular, architectural or radical innovations, depending on which system they replaced. In a study of energy efficiency patents, Noailly (2012) confirms these conclusions for a larger sample of European countries: the building-related patents were mainly related to improvements in boilers (incremental innovations) and insulation (incremental or possibly modular innovations) and energy demand reduction.

\subsection{Effects of technology-specific economic instruments on innovation}

Technology-specific economic instruments in the automotive sector include subsidies to specific fuels and public procurement directed at specific solutions, such as electric or hybrid-electric vehicles. As mentioned previously, we have not been able to find any studies of the innovation impact of fuel subsidies, so we will focus on public procurement. 
Public procurement is a long-standing research area in innovation studies (see Edquist and Zabala-Iturriagagoitia, 2012). An important example of public procurement to support introduction of low-emitting vehicles is the program initiated at Transport for London (TfL) in 2006 to try out buses with alternative power trains. This included a large-scale comparative test of diesel electric hybrid configurations from several competing suppliers. By 2011, this test had expanded into a five-year evaluation program, covering eight different technology types, and a long term goal that all new buses delivered after 2012 would be hybrid vehicles. In addition to testing various technological solutions, the program envisaged a reduction of the initial $50 \%$ price premium for the new technology, in line with volume increases. A study by Sushandoyo and Magnusson (2014) shows that in terms of scale, public visibility and timing this was a very important project for bus manufacturers in Europe and system specialists across the Atlantic, helping them to focus their efforts, choose between alternative solutions and start or ramp up series production. The Volvo Group, for example, had just presented prototypes of hybrid electric buses when the TfL program started and encouraged the company to commercialize this previously unproven technology configuration. In the words of the technical director at Volvo Powertrain: "Until then, we had only built demonstration vehicles. We were now going to develop an entirely new driveline for vehicles on the market" (Hanssen, 2011). At the time of writing, the TfL program cannot be conclusively evaluated, but for Volvo Bus the London program seems to have been crucial both for real world-testing and continuous technical development, contributing to the company's decision to make hybrid-electric powertrains - an architectural innovation - the standard option in their future city bus 
program, and the London program has also led to significant efforts among various other firms.

In the energy sector, investment subsidies and production premiums of various sorts have been applied for specific renewables such as wind power and solar cells. Johnstone et al. (2010b) conclude that such instruments have had a generally positive effect on patenting in renewables, although this effect varies substantially between technologies and instruments. For example, investment subsidies have had a positive effect on patenting in biomass, geothermal and solar technologies and production premiums only on solar energy patenting. ${ }^{17}$ As noted earlier, however, this study does not analyse what types of inventions are patented. Studies of specific policies give a more detailed picture of their innovation outcomes. Here we will focus on the German electricity feed-in law (EFL) of 1990. It required electricity distributors to buy power from producers of renewable electricity (small-scale hydro, landfill gas, biomass, geothermal, onshore and offshore wind and solar cells) and pay them a price corresponding to $60-95 \%$ of the average consumer price for electricity (Lauber and Mez, 2004). Tariffs were technologyspecific, in that more mature technologies received a lower price than less developed, more expensive ones, and from 2000 prices for new plants were reduced annually (Mitchell et al., 2006). Studies of the development and diffusion of renewable energy systems show that the EFL has been a major contributing factor to Germany's industrial dynamics in these areas. The EFL has contributed both to modular and radical innovation in wind turbines and solar cells, and to incremental innovations in all relevant

\footnotetext{
${ }^{17}$ It should be noted, though, that this patent data set does not seem to be a good reflection of innovation in the case of wind power: The yearly patent counts in the database are quite low before the late 1990s, in spite of the fact that several detailed case studies have showed that there were a lot of inventive and innovative activities in the 1970s, 1980s and early 1990s in several countries (cf., e.g., Bergek and Jacobsson, 2003; Kamp et al., 2004; Karnøe, 1990, 1995).
} 
industries (cf. Bergek and Jacobsson, 2003; Büsgen and Dürrschmidt, 2009; Jacobsson and Lauber, 2006; Negro and Hekkert, 2008). ${ }^{18}$

Spain also implemented a feed-in systems in 1997, when the Law of the Electricity Sector provided renewable electricity producers grid access, and a 80-90\% price premium, guaranteed for the whole lifetime of each plant and descending for new plants (del Río González, 2008). According to evaluation studies, the system has primarily stimulated the diffusion of wind power in Spain, but there is also some evidence that manufacturing costs for wind turbines and solar cells have been reduced more in Spain than in countries without feed-in tariffs (del Río and Gual, 2007).

\subsection{Effects of technology-specific regulatory instruments on innovation}

Technology-specific regulatory instruments in the automotive sector include the wellknown zero emission vehicle-rule from 1990, mandated by Californian authorities who were encouraged by the success of previous emissions regulation, and the electrical vehicles demonstrated by GM (Shnayerson, 1996). This regulation aimed at eliminating all hazardous tailpipe pollution by requiring automotive majors to introduce emissionfree vehicles for a rapidly increasing part of their sales, $2 \%$ in $1998,5 \%$ in 2001 , and $10 \%$ in 2003 . Technically the ZEV rule was a performance standard, but since at the time only one zero-emitting propulsion technology was available, i.e. electric propulsion, it was in reality a technological standard. The ZEV mandate tried to enforce the market diffusion of an entirely new vehicle architecture including entirely new components, i.e. a radical innovation. Moreover, this could not be developed and tested

\footnotetext{
${ }^{18}$ Several of these studies are comparative case studies, which to some extent isolates the effect of the German EFL from effects of instruments and events in other countries.
} 
in any gradual way, but had to be introduced in one package competing on cost, reliability and performance with conventional cars (Collantes and Sperling, 2008; Sperling and Gordon, 2009).

The ZEV-rule inspired start-up firms in the electrical vehicle field and new collaborative networks in battery technologies (Pilkington et al., 2002), where developments in nickel cadmium and metal hydride technologies created expectations of a breakthrough for electrical vehicles. In the period following the mandate EV-related patenting activities increased (Pilkington et al., 2002) and all major automakers launched battery electric cars in small quantities, such as GM EV1, Ford Ranger EV, and Toyota RAV4 EV (Bergek et al., 2013). The fundamental intention with the legislation - to enforce the conversion of the Californian vehicle fleet to zero-emitting vehicles - failed. However, it can be argued that the ZEV-mandate had a long-term effect on the further development of electrical cars later embodied in increasingly competitive EVs launched after 2010, more than 20 years after the enactment of California's legislation. This observation highlights the well-known fact that radical innovations in established systems need a long time to evolve and mature.

In the energy sector, direct regulation includes the identification of Best Available Techniques (BAT) for energy efficiency in industry under the IPPC Directive, which prescribes very specific solutions for different applications, such as replacing conventional electric motors with variable speed drives in energy-using systems, processes or equipment (European IPPC Bureau, 2009). However, as mentioned in Section 3, we have not found any empirical studies of the innovation impact of such instruments. 


\subsection{Synthesis and comparison}

Table 3 summarizes the experiences of the four main types of policy instruments in the two studied sectors. The similarity between the sectors with regard to the outcomes of the four types of policy instruments is striking. In both sectors, general economic instruments have primarily induced incremental innovation and diffusion of relatively mature technologies, as the studies of emissions trading, $\mathrm{NO}_{\mathrm{x}} \mathrm{REPs}$ and green certificates indicate, ${ }^{19}$ but also encouraged $R \& D$ and demonstration of complex modular innovation. However, there is a vast difference between stimulating initial development of a new technology and achieving its widespread diffusion. This is demonstrated by CCS, where general economic instruments have been insufficient to stimulate commercial application due to the scale of the required investments (Hoffmann, 2007; van Alphen et al., 2009).

General regulatory instruments can be effective in driving development and diffusion of incremental and modular innovations, as evidenced from both sectors. Diffusion of modular innovations is especially important for the mass-production oriented automotive sector, where penetration is critical for success. It is difficult to envisage economic means that would match the effectiveness of the CAAA-legislation or the corresponding Euro I - VI framework in driving innovation and deep emissions reduction (cf. Bergquist et al. (2013) for parallel studies of a different sector). However, this type of regulation is difficult to apply if more radical and comprehensive innovations are needed.

\footnotetext{
${ }^{19}$ A similar conclusions was drawn by Brouillat and Oltra (2012), who used an agent-based model to explore the influence of extended producer responsibility instruments on eco-design innovation strategies.
} 
Finally, technology-specific instruments - both economic and regulatory - seem to be necessary to support architectural and radical innovations, from their early development, via market introduction, to the critical diffusion stages.

However, the review also shows that these innovation effects depend on other factors, for example the maturity of the targeted technologies and the level of support provided. We will return to these issues in the next section.

\section{Conclusions and discussion}

\subsection{The impact of environmental policy and the importance of design features}

A first conclusion of the paper concerns the key role of policies for realizing innovations in the studied sectors. Although the main motive of environmental policy is to reduce emissions and other types of negative impacts on the environment, there is now a renewed interest in large-sale publicly funded programs to develop entirely new technologies in response to "the grand challenges" facing modern societies (cf., e.g., Foray et al., 2012). This paper shows that there are now a number of policy instruments, regulatory as well as economic, which have been evaluated as successful in terms of both emissions reduction and innovation impact (defined as their contribution to the development, market introduction and early diffusion of new or refined technologies which reduce undesirable emissions). 
Table 3: Innovation effects of four types of policy instruments in two sectors

\begin{tabular}{|c|c|c|c|c|}
\hline Type & Sector & Instrument & Positive impact on: & Limited or no impact on: \\
\hline \multirow[t]{4}{*}{$\begin{array}{l}\text { General } \\
\text { economic }\end{array}$} & Automotive & Fuel taxes & $\begin{array}{l}\text { - Development and diffusion of incremental innovations in } \\
\text { conventional technologies. } \\
\text { - Diffusion of modular technology (diesel engines) }\end{array}$ & $\begin{array}{l}\text { - Development and diffusion of fuel saving } \\
\text { modular innovations. }\end{array}$ \\
\hline & \multirow[t]{3}{*}{ Energy } & EU ETS & $\begin{array}{l}\text { Development and diffusion of incremental innovations in } \\
\text { conventional technologies. } \\
\text { - Development of complex modular innovation (CCS) }\end{array}$ & $\begin{array}{l}\text { Market introduction and diffusion of complex } \\
\text { modular innovations (CCS) } \\
\text { " Development of renewable energy } \\
\text { technologies. }\end{array}$ \\
\hline & & Swedish $\mathrm{NO}_{\mathrm{x}} \mathrm{REP}$ & $\begin{array}{l}\text { - Diffusion of available abatement technologies } \\
\text { - Incremental innovations in conventional technologies }\end{array}$ & \\
\hline & & TGC & $\begin{array}{l}\text { Diffusion (and some cases of incremental improvements) } \\
\text { of relatively mature renewable energy technologies. }\end{array}$ & $\begin{array}{l}\text { Development and diffusion of modular, } \\
\text { architectural or radical innovations (especially } \\
\text { more immature renewable energy } \\
\text { technologies). }\end{array}$ \\
\hline \multirow[t]{3}{*}{$\begin{array}{l}\text { General } \\
\text { regulatory }\end{array}$} & Automotive & $\begin{array}{l}\text { CAAA and similar } \\
\text { European emissions } \\
\text { regulations }\end{array}$ & $\begin{array}{l}\text { Development and diffusion of modular innovations } \\
\text { (catalytic converters, clean diesel technologies, fuel- } \\
\text { saving modules) and improvements in existing } \\
\text { technologies. }\end{array}$ & $\begin{array}{l}\text { Development and diffusion of architectural or } \\
\text { radical innovation. }\end{array}$ \\
\hline & \multirow[t]{2}{*}{ Energy } & CAAA & $\begin{array}{l}\text { " Diffusion of existing modular innovations (scrubbers). } \\
\text { " Development and diffusion of modular innovation } \\
\text { (CCGT). }\end{array}$ & $\begin{array}{l}\text { Diffusion of new architectural innovation } \\
\text { (PFBC) for clean coal. }\end{array}$ \\
\hline & & $\begin{array}{l}\text { Dutch building } \\
\text { regulations }\end{array}$ & $\begin{array}{l}\text { Incremental innovation in conventional water heating } \\
\text { technologies. }\end{array}$ & $\begin{array}{l}\text { - Development and diffusion of architectural } \\
\text { innovations (solar how water boilers, heat } \\
\text { pumps) }\end{array}$ \\
\hline \multirow{3}{*}{$\begin{array}{l}\text { Technology- } \\
\text { specific } \\
\text { economic }\end{array}$} & \multirow[t]{2}{*}{ Automotive } & \multicolumn{3}{|c|}{ Not included in the review } \\
\hline & & Public procurement & $\begin{array}{l}\text { - Development and market introduction of architectural } \\
\text { innovation (hybrid-electric buses) }\end{array}$ & \\
\hline & Energy & Feed in tariffs & $\begin{array}{l}\text { - Development and diffusion of architectural and radical } \\
\text { innovations (e.g. wind turbines, solar PV cells) }\end{array}$ & $\begin{array}{l}\text { Development and diffusion of technologies not } \\
\text { included in the tariffs. }\end{array}$ \\
\hline \multirow{2}{*}{$\begin{array}{l}\text { Technology- } \\
\text { specific } \\
\text { regulatory }\end{array}$} & Automotive & ZEV & $\begin{array}{l}\text { - Development and first market introduction of } \\
\text { architectural innovation (electric cars) }\end{array}$ & $\begin{array}{l}\text { Further development and diffusion of electric } \\
\text { cars. }\end{array}$ \\
\hline & Energy & \multicolumn{3}{|c|}{ Not included in the review } \\
\hline
\end{tabular}


Second, in the real world there is no one best way, no one best instrument. In the cases reviewed in this paper, different types of instruments promote different types of innovations: general economic instruments tend to encourage diffusion and incremental innovation; general regulatory instruments enforce significant improvements based on modular innovation; and technologyspecific instruments appear to be required for the development and deployment of radically new technologies, although the fostering of upgrades and cost reductions is necessary for all policies. There are some important differences between the two studied sectors - most notably, direct regulation has been more effective in driving modular innovations in the automotive sector than in the energy sector - but overall the innovation outcomes of different policy instruments seem to be similar across the two sectors. If policy makers were made aware of such differences, they would be better equipped to select environmental policy instruments that match their goals in terms of innovation. For example, they would not expect innovation outcomes when they are unlikely to materialize and could refrain from using certain types of instruments when innovation is not a prioritized goal.

The paper has focused on the innovation impacts of economic versus regulatory and general versus technology specific instruments, which can be compared across cases and sectors. As noted in the introduction, the impact of an instrument is also related to aspects such as stringency, predictability and other design and implementation issues (cf. Johnstone et al., 2010a). These are very difficult to compare across cases and sectors and the studies reviewed here do not provide sufficient information to support any robust conclusions. Several studies report important design effects, however, which are highlighted in the discussion below. Taken together, they indicate that all the studied instruments face design and implementation challenges, such as: 
- Selection. For technology-specific policies, the dangers involved in trying to select winners have been discussed at length. However, it is clear from the empirical studies referred to above that also general instruments lead to selection, for example, of mature over less mature technologies or incremental/modular over architectural/radical innovations. In some of the cases analysed in this paper, this bias may have been unintended. However, an implicit selection can often be predicted beforehand, based on performance and cost comparisons between technologies. Such information should be taken into account when choosing between different instruments.

- Stringency. Stringency is a critical issue for all of the instruments reviewed in this paper (cf. Kemp and Pontoglio, 2011) and has been noted as an important design aspect in several of the cases above. The reviewed studies do no focus on stringency per se, but on the role of stringency increases, which involves complex processes of learning, lobbying and negotiations (cf. Lee et al., 2010). Initial stringency tends to be the result of an uncertain search process and the examples indicate the importance of successive stringency increases, otherwise innovative efforts will tend to fade out. The significance of this is illustrated both in the power sector (the German feed-in system) and in the automotive sector (the Euro I - VI framework with significant tightening of standards five times over a 20-year period). There seems to be a "law of increasing stringency" applicable to both economic and regulatory instruments; to have any lasting innovation impact, allocations in trading systems need to be tightened, and so do fuel taxes or regulatory standards.

- Stability or the opposite, uncertainty, has also been discussed in various reports and articles, but often in relation to investments rather than to innovation (e.g. Barradale, 
2010). In capital-intensive sectors, such as the automotive and energy sectors, the perceived stability of policy instruments over an extended period of time is of particular importance. The exact levels of economic support or regulatory standards are usually less important than their predictability. The studies analyzed in this paper suggest that taxes and investment subsidies have been less favorable than standards from this perspective. The effect of a fuel tax, for example, is determined by the final fuel price, which tends to be highly volatile in relation to the long lead times needed to develop and test new complex systems, whereas regulation tends to be more stable, as borne out by studies of automotive emissions regulation in the US and Europe (cf. Berggren and Magnusson, 2012; Clerides and Zachariadis, 2008; Greene, 1990). General conclusions regarding the stability of a specific type of instrument are difficult to justify, however, since stability is dependent on institutional environment and implementation. For example, regulatory instruments at the EU level are legally implemented at an international institutional level, which increases their stability compared with nationally confined regulations.

- Scale. To be effective, technology-specific economic instruments directed at capitalintensive industries have to be salient for relevant industrial decision-makers, and thus tend to involve heavy resource commitments. The program for procurement and evaluation of hybrid electric buses in London represents such a case, where the volume of purchased vehicles is significant in relation to total UK sales. However, large-scale programs can over time lead to legitimacy problems and cost concerns if subsidy levels (i.e. stringency levels) are not properly adjusted. The German feed-in system has been hugely successful in supporting the diffusion of PV solar cells, enabling manufacturers to ramp up production and cut price per module (a 50\% reduction 2006-11). However, this 
cost reduction was not envisaged when policy makers decided on reductions in the tariff levels, resulting in a relative increase in subsidy per installed unit. When solar installations increased exponentially, with a quadrupling in installed capacity 2007-10, subsidy costs ballooned, leading to difficult political negotiations about how to more rapidly reduce the subsidies (Grau et al., 2012). From a different perspective, this can be seen as a necessary learning process in instrument design and implementation (see Flanagan et al., 2011).

\subsection{Limitations and future research}

This review has shown the co-variation of various policies and innovation impacts. A further step would be to develop comparative approaches which can establish more robust causal relationships, by comparing the innovation impacts or non-impacts, when the same, or similar, policy instruments are applied in different contexts; and vice versa, select similar environmental innovation processes across several countries and investigate if they are related to similar policy interventions or can be explained by other factors.

This review analyzes reports which mainly study instruments in isolation, although it has been noted that economic instruments also require a proper regulatory framework. In real life policymaking, instruments are often combined and interacting. Several researchers have noted the importance of designing public policy as a portfolio of economic and regulatory instruments (cf. Veugelers, 2012). As emphasized in Flanagan et al. (2011: 711), however, "policy processes are no more amenable to instrumental rationality than are innovation processes" and policy portfolios or mixes may thus contain contradictory elements, underlining the role of "policy learning". An important area for further research is to analyse different types of policy interactions and learning 
mechanisms, and the processes of shaping portfolios needed for long-term evolution of radically new technologies, including support for R\&D and network building.

A related area concerns the interaction between instrument types and design features. Above, the importance of increasing stringency levels has been noted. It could be argued that policy instruments differ substantially regarding the possibility to increase their stringency. Both in the US and the EU, for example, it seems less difficult for policymakers to increase the stringency of standards than to raise the level of taxation, such as fuel taxes. ${ }^{20}$ So far this type of interaction has not been studied in a systematic way, but given the importance of increasing stringencies for innovation, it should be an important theme for future studies.

\section{Acknowledgements}

Funding from Riksbankens Jubileumsfond and constructive comments from several anonymous reviewers are gratefully acknowledged.

\section{References}

Andersson, B.A., Jacobsson, S., 2000. Monitoring and assessing technology choice: the case of solar cells. Energy Policy 28, 1037-1049.

Bañales-López, S., Norberg-Bohm, V., 2002. Public policy for energy technology innovation: A historical analysis of fluidized bed combustion development in the USA. Energy Policy 30, 1173-1180.

\footnotetext{
${ }^{20}$ As mentioned previously, it can be politically difficult to set high enough carbon taxes to induce the required innovation efforts (Fischer et al., 2012), whereas standards are often less visible to potential voters. Similarly, Johnstone et al. (2010b) argue that it is more difficult politically to raise taxes than to increase stringency for "less transparent" economic instruments such as TGCs. A variant of this argument is presented by Jaffe (2005) in his discussion about why subsidy policies tend to gain more political support than potentially more effective environmental tax policies.
} 
Barradale, M.J., 2010. Impact of public policy uncertainty on renewable energy investment: Wind power and the production tax credit. Energy Policy 38, 7698-7709.

Bauner, D., Laestadius, S., Iida, N., 2009. Evolving technological systems for diesel engine emission control: balancing GHG and local emissions. Clean Techn Environ Policy 11, 339-365.

Beerepoot, M., Beerepoot, N., 2007. Government regulation as an impetus for innovation: Evidence from energy performance regulation in the Dutch residential building sector. Energy Policy 35, 4812-4825.

Bellas, A.S., 1998. Empirical evidence of advances in scrubber technology. Resource and Energy Economics 20, 327-343.

Bergek, A., Berggren, C., Magnusson, T., Hobday, M., 2013. Technological discontinuities and the challenge for incumbent firms: Destruction, disruption or creative accumulation? Research Policy 42, 1210-1224.

Bergek, A., Jacobsson, S., 2003. The Emergence of a Growth Industry: A Comparative Analysis of the German, Dutch and Swedish Wind Turbine Industries, in: Metcalfe, S., Cantner, U. (Eds.), Change, Transformation and Development. Physica-Verlag, Heidelberg, pp. 197227.

Bergek, A., Jacobsson, S., 2010. Are tradable green certificates a cost-efficient policy driving technical change or a rent-generating machine? Lessons from Sweden 2003-2008. Energy Policy 38, 1255-1271.

Berggren, C., Magnusson, T., 2012. Reducing automotive emissions-The potentials of combustion engine technologies and the power of policy. Energy Policy 41, 636-643.

Berggren, C., Magnusson, T., Sushandoyo, D., 2009. Hybrids, diesel or both? The forgotten technological competition for sustainable solutions in the global automotive industry. International Journal of Automotive Technology and Management 9, 148-173.

Bergquist, A.-K., Söderholm, K., Kinneryd, H., Lindmark, M., Söderholm, P., 2013. Commandand-control revisited: Environmental compliance and technological change in Swedish industry 1970-1990. Ecological Economics 85, 6-19.

Brouillat, E., Oltra, V., 2012. Extended producer responsibility instruments and innovation in eco-design: An exploration through a simulation model. Ecological Economics 83, 236245.

Butler, L., Neuhoff, K., 2008. Comparison of feed-in tariff, quota and auction mechanisms to support wind power development. Renewable Energy 33, 1854-1867.

Büsgen, U., Dürrschmidt, W., 2009. The expansion of electricity generation from renewable energies in Germany: A review based on the Renewable Energy Sources Act Progress Report 2007 and the new German feed-in legislation. Energy Policy 37, 2536-2545.

Chappin, M.M.H., Vermeulen, W.J.V., Meeus, M.T.H., Hekkert, M.P., 2009. Enhancing our understanding of the role of environmental policy in environmental innovation: adoption explained by the accumulation of policy instruments and agent-based factors.

Environmental Science \& Policy 12, 934-947.

Clerides, S., Zachariadis, T., 2008. The effect of standards and fuel prices on automobile fuel economy: An international analysis. Energy Economics 30, 2657-2672.

Collantes, G., Sperling, D., 2008. The origin of California's zero emission vehicle mandate. Transportation Research Part A: Policy and Practice 42, 1302-1313.

del Río González, P., 2008. Ten years of renewable electricity policies in Spain: An analysis of successive feed-in tariff reforms. Energy Policy 36, 2917-2929. 
del Río, P., Gual, M.A., 2007. An integrated assessment of the feed-in tariff system in Spain. Energy Policy 35, 994-1012

Demirel, P., Kesidou, E., 2011. Stimulating different types of eco-innovation in the UK: Government policies and firm motivations. Ecological Economics 70, 1546-1557.

Dings, J., 2010. How clean are Europe's cars? An analysis of carmaker progress towards EU CO2 targets in 2009. European Federation for Transport and Environment, Brussels.

Dings, J., 2011. How clean are Europe's cars? An analysis of carmaker progress towards EU CO2 targets in 2010. European Federation for Transport and Environment, Brussels.

do Valle Costa, C., La Rovere, E., Assmann, D., 2008. Technological innovation policies to promote renewable energies: Lessons from the European experience for the Brazilian case. Renewable and Sustainable Energy Reviews 12, 65-90.

Edquist, C., Zabala-Iturriagagoitia, J.M., 2012. Public Procurement for Innovation as missionoriented innovation policy. Research Policy 41, 1757-1769.

European IPPC Bureau, 2009. Reference Document on Best Available Techniques for Energy Efficiency Edificio Expo Sevilla.

Fischer, C., Torvanger, A., Shrivastava, M., Sterner, T., Stigson, P., 2012. How Should Support for Climate-Friendly Technologies Be Designed? Ambio 41, 33-45.

Flanagan, K., Uyarra, E., Laranja, M., 2011. Reconceptualising the 'policy mix' for innovation. Research Policy 40, 702-713.

Foray, D., Mowery, D.C., Nelson, R.R., 2012. Public R\&D and social challenges: What lessons from mission R\&D programs? Research Policy 41, 1697-1702.

Foxon, T.J., Gross, R., Chase, A., Howes, J., Arnali, A., Anderson, D., 2005. UK innovation systems for new and renewable energy technologies: drivers, barriers and system failures. Energy Policy 33, 2123-2137.

Goulder, L.H., Parry, I.W.H., 2008. Instrument Choice in Environmental Policy. Review of Environmental Economics and Policy 2, 152-174.

Grau, T., Huo, M., Neuhoff, K., 2012. Survey of photovoltaic industry and policy in Germany and China. Energy Policy 51, 20-37.

Greene, D., 2010. Why the Market for New Passenger Cars Generally Undervalues Fuel Economy, Joint Transport Research Centre Round Table 18-19 February 2010. OECD/International Transport Forum, Paris.

Greene, D.L., 1990. CAFE OR PRICE?: An Analysis of the Effects of Federal Fuel Economy Regulations and Gasoline Price on New Car MPG, 1978-89. The Energy Journal 11, 37-57.

Grubb, M., Ulph, D., 2002. Energy, the environment, and innovation. Oxford Review of Economic Policy 18, 92-106.

Hanssen, S., 2011. Hybrids is one of my greatest passions. Volvo Group Global News, 8 December 2011.

Henderson, R.M., Clark, K.B., 1990. Architectural Innovation: The Reconfiguration of Existing Product Technologies and the Failure of Established Firms. Administrative Science Quarterly 35, 9-30.

Hillman, K.M., Suurs, R.A.A., Hekkert, M.P., Sanden, B.A., 2008. Cumulative causation in biofuels development: A critical comparison of the Netherlands and Sweden. Technology Analysis and Strategic Management 20, 593-612.

Hoffmann, V., 2007. EU ETS and Investment Decisions: The Case of the German Electricity Industry. European Management Journal 25, 464-474.

Jacobsson, S., Johnson, A., 2000. The Diffusion of Renewable Energy Technology: An Analytical Framework and Key Issues for Research. Energy Policy 28, 625-640. 
Jacobsson, S., Lauber, V., 2006. The politics and policy of energy system transformationexplaining the German diffusion of renewable energy technology. Energy Policy 34, 256276.

Jaffe, A.B., Newell, R.G., Stavins, R.N., 2002. Environmental Policy and Technological Change. Environmental and Resource Economics 22 41-69.

Jaffe, A.B., Newell, R.G., Stavins, R.N., 2005. A tale of two market failures: Technology and environmental policy. Ecological Economics 54, 164-174.

Johnstone, N., Hašcic, I., Kalamova, M., 2010a. Environmental Policy Design Characteristics and Technological Innovation: Evidence from Patent Data. OECD, Paris Cedex.

Johnstone, N., Haščič, I., Popp, D., 2010b. Renewable Energy Policies and Technological Innovation: Evidence Based on Patent Counts. Environmental and Resource Economics 45, 133-155.

Junginger, M., Faaij, A., Turkenburg, W.C., 2005. Global experience curves for wind farms. Energy Policy 33, 133-150.

Kamp, L.M., Smits, R.E.H.M., Andriesse, C.D., 2004. Notions on learning applied to wind turbine development in the Netherlands and Denmark. Energy Policy 32, 1625-1637.

Karnøe, P., 1990. Technological innovation and industrial organization in the Danish wind industry. Entrepreneurship \& Regional Development 2, 105-124.

Karnøe, P., 1995. Institutional Interpretations and Explanations of Differences in American and Danish Approaches to Innovation, in: Scott, W.R., and, Christensen, S. (Eds.), The Institutional Construction of Organizations: International and Longitudinal Studies. SAGE Publications, Thousand Oaks, pp. 243-276.

Kemp, R., Pontoglio, S., 2011. The innovation effects of environmental policy instruments - A typical case of the blind men and the elephant? Ecological Economics 72, 28-36.

Kline, S., and, Rosenberg, N., 1986. An Overview of Innovation, in: Landau, R., and, Rosenberg, N. (Eds.), The Positive Sum Strategy. National Academy Press, Washington D.C., pp. 275305.

Knecht, W., 2008. Diesel engine development in view of reduced emission standards. Energy 33, 264-271

Lauber, V., Mez, L., 2004. Three decades of renewable electricity policies in Germany. Energy \& Environment 15, 599-623.

Lee, J., Veloso, F.M., Hounshell, D.A., Rubin, E.S., 2010. Forcing technological change: A case of automobile emissions control technology development in the US. Technovation 30, 249264.

Lovio, R., Kivimaa, P., 2012. Comparing Alternative Path Creation Frameworks in the Context of Emerging Biofuel Fields in the Netherlands, Sweden and Finland. European Planning Studies 20, 773-790.

Löfstedt, R.E., Vogel, D., 2001. The Changing Character of Regulation: A Comparison of Europe and the United States. Risk Analysis 21, 399-416.

Macher, J.T., Richman, B.D., 2004. Organisational responses to discontinuous innovation: a case study approach. International Journal of Innovation Management 8, 87-114.

Malerba, F., 2002. Sectoral systems of innovation and production. Research Policy 31, 247-264.

Mitchell, C., Bauknecht, D., Connor, P.M., 2006. Effectiveness through risk reduction: a comparison of the renewable obligation in England and Wales and the feed-in system in Germany. Energy Policy 34, 297-305. 
Negro, S.O., Hekkert, M.P., 2008. Explaining the success of emerging technologies by innovation system functioning: the case of biomass digestion in Germany. Technology Analysis \& Strategic Management 20, 465-482.

Noailly, J., 2012. Improving the energy efficiency of buildings: The impact of environmental policy on technological innovation. Energy Economics 34, 795-806.

Noailly, J., Batrakova, S., 2010. Stimulating energy-efficient innovations in the Dutch building sector: Empirical evidence from patent counts and policy lessons. Energy Policy 38, 78037817.

OECD, 2005. Environmentally Harmful Subsidies: Challenges for Reform. OECD, Paris.

Pavitt, K., 1984. Sectoral patterns of technical change: Towards a taxonomy and a theory. Research Policy 13, 343-373.

Perlin, J., 1999. From Space to Earth: The Story of Solar Electricity. aatec publications, Ann Arbor, Michigan.

Pilkington, A., Dyerson, R., Tissier, O., 2002. The electric vehicle:: Patent data as indicators of technological development. World Patent Information 24, 5-12.

Popp, D., 2003. Pollution control innovations and the Clean Air Act of 1990. Journal of Policy Analysis and Management 22, 641-660.

Popp, D., 2006. International innovation and diffusion of air pollution control technologies: the effects of NOX and SO2 regulation in the US, Japan, and Germany. Journal of Environmental Economics and Management 51, 46-71.

Popp, D., Newell, R.G., Jaffe, A.B., 2009. Energy, the environment, and technological change, NBER Working Paper Series, Cambridge, MA.

Praetorius, B., Martiskainen, M., Sauter, R., Watson, J., 2010. Technological innovation systems for microgeneration in the UK and Germany - a functional analysis. Technology Analysis \& Strategic Management 22, 745-764.

Requate, T., 2005. Dynamic incentives by environmental policy instruments - a survey. Ecological Economics 54, 175-195.

Rogge, K.S., Hoffmann, V.H., 2010. The impact of the EU ETS on the sectoral innovation system for power generation technologies - Findings for Germany. Energy Policy 38, 7639-7652.

Rogge, K.S., Schneider, M., Hoffmann, V.H., 2011. The innovation impact of the EU Emission Trading System - Findings of company case studies in the German power sector. Energy Economics 70, 513-523.

Sandén, B.A., Azar, C., 2005. Near-term technology policy for long-term climate targets economy wide versus technology specific approaches. Energy Policy 33, 1557-1576.

Shnayerson, M., 1996. The Car that Could. The Inside Story of GM's Revolutionary Electric Vehicle. Random House, New York.

Sperling, D., Gordon, D., 2009. Two billion cars. Oxford University Press, Oxford.

Stavins, R.N., 2003. Experiences with market-based environmental policy instruments, in: Mäler, K.-G., Vincent, J. (Eds.), The Handbook of Environmental Economics. NorthHolland/Elsevier Science Amsterdam.

Sterner, T., 2012. Fuel Taxes and the Poor, The Distributional Effects of Gasoline Taxation and Their Implications for Climate Policy, Washington, D.C.

Sterner, T., Turnheim, B., 2009. Innovation and diffusion of environmental technology: Industrial NOx abatement in Sweden under refunded emission payments. Ecological Economics 68, 2996-3006. 
Sushandoyo, D., Magnusson, T., 2014. Strategic niche management from a business perspective: Taking cleaner vehicle technologies from prototype to series production. Journal of Cleaner Production 74, 17-26.

Söderholm, P., Klaassen, G., 2007. Wind Power in Europe: A Simultaneous InnovationDiffusion Model. Environmental and Resource Economics 36, 163-190.

Tao, L., Garnsey, E., Probert, D., Ridgman, T., 2010. Innovation as response to emissions legislations: Revisiting the automotive catalytic converter at Johnson Matthey. R\&D Management 40, 154-167.

Taylor, M.R., Rubin, E.S., Hounshell, D.A., 2005. Control of SO2 emissions from power plants: A case of induced technological innovation in the U.S. Technological Forecasting and Social Change 72, 697-718.

van Alphen, K., Hekkert, M.P., Turkenburg, W.C., 2009. Comparing the development and deployment of carbon capture and storage technologies in Norway, the Netherlands, Australia, Canada and the United States- An innovation system perspective. Energy Procedia 1, 4591-4599.

van Alphen, K., Noothout, P.M., Hekkert, M.P., Turkenburg, W.C., 2010. Evaluating the development of carbon capture and storage technologies in the United States. Renewable and Sustainable Energy Reviews 14, 971-986.

Vasseur, V., Kamp, L.M., Negro, S.O., 2013. A comparative analysis of Photovoltaic Technological Innovation Systems including international dimensions: the cases of Japan and The Netherlands. Journal of Cleaner Production 48, 200-210.

Verbruggen, A., 2009. Performance evaluation of renewable energy support policies, applied on Flanders' tradable certificates system. Energy Policy 37, 1385-1394.

Veugelers, R., 2012. Which policy instruments to induce clean innovating? Research Policy 41, 1770-1778.

Weyant, J.P., 2011. Accelerating the development and diffusion of new energy technologies: Beyond the "valley of death". Energy Economics 33, 674-682.

Wood, G., Dow, S., 2011. What lessons have been learned in reforming the Renewables Obligation? An analysis of internal and external failures in UK renewable energy policy. Energy Policy 39, 2228-2244.

Yin, H., Powers, N., 2010. Do state renewable portfolio standards promote in-state renewable generation?. Energy Policy 38, 1140-1149. 